\title{
Przyszłościowe wspólbieżne mikroprocesorowe inteligentne systemy mechatroniczne w sterowaniu i diagnostyce pojazdów szynowych (1)
}

\author{
$W$ artykule przedstawiono przyszłościowe rozproszone współbieżne mikroprocesorowe \\ inteligentne systemy mechatroniczne w sterowaniu i diagnostyce pojazdów szynowych. Systemy \\ te będa podstawa do tworzenia różnych modeli i uktadów informatycznych i informacyjnych dla \\ pojazdów szynowych. Artykut sktada się z kilku części. Pierwsza część artykutu (1) obejmuje \\ ogólne wiadomości na temat problemów rozproszonych układów sterowania oraz stosowanych \\ modeli sieci CAN. Zawiera informacje na temat stosowanych systemów sterowania przez firmy \\ europejskie. \\ Artykut powstał w wyniku realizacji projektu badawczego KBN 4 T 12 C 04929 pt. „Rozproszone \\ wspótbieżne mikroprocesorowe inteligentne podsystemy mechatroniczne $w$ sterowaniu i diagno- \\ styce pojazdów szynowych".
}

\section{Wprowadzenie}

Nowoczesne pojazdy szynowe wyposażane są w podzespoły na coraz wyższym poziomie technicznym, wykorzystujące nowe technologie elektroniczne i informatyczne. Współczesny wyspecjalizowany tabor szynowy będzie coraz częściej wymagał zastosowania układów sterujących z wykorzystaniem inteligentnych podsystemów mechatronicznych, co jest szczególnie przydatne do rozwiązywania problemów, gdzie zastosowanie metod konwencjonalnych byłoby bardzo trudne lub niemożliwe.

Dotychczasowe doświadczenia w zakresie sterowania pojazdami szynowymi oraz w zakresie elektroniki i technik informatycznych, stosowanych na tych pojazdach, wskazują na potrzebe podjęcia prac badawczych nad zastosowaniem rozproszonych współbieżnych (równoległych z pewnymi ograniczeniami) inteligentnych podsystemów mechatronicznych w sterowaniu i diagnostyce pojazdów szynowych.

Do realizacji przyszłościowego systemu istotne jest tworzenie nowych struktur sprzętu i oprogramowania poprzez:

- przesunięcie strefy cyfrowej (zanik klasycznego bloku analogowego i stopniowa eliminacja przetworników A/C) w kierunku sensorów pomiarowych, co polepsza własności pomiarowe

- zastosowanie najnowszych układów elektronicznych jako elementów sprzęgających, (uniwersalne interfejsy do przetworników)

- zastosowanie układów licznikowych, do których podłączone są bezpośrednio sensory pomiarowe

- wprowadzenie cyfrowo sterowanych układów wykonawczych, co poprawia dokładność i zwiększa niezawodność pracy.

Podsystemy mechatroniczne pojazdów szynowych będą tworzyć rozległe systemy oparte na modelach rozproszonej (zdecentralizowanej) sztucznej inteligencji DAI (Distributed Artificial Intelligen- ce) i związanych z nimi - programach agentowych (autonomicznego lub aktywnego agenta - Autonomous or, Active Agent). Wysoka modularność środowisk agentowych sprawia, iż z punktu widzenia inżynierii oprogramowania mogą one stanowić specjalny przypadek systemów obiektowo zorientowanych, w których pojedyncze obiekty mają swoje własne wątki wykonania oraz swoje własne indywidualne zadania. Zastosowanie systemów wieloprocesorowych, pracujących równolegle $\mathrm{w}$ sieci połączeń wielokrotnie zwiększa możliwości obliczeniowe. Zdecentralizowana sztuczna inteligencja DAI jest dziedziną wiedzy, która składa się z dwóch poddziedzin:

- rozproszone rozwiązywanie problemów DSP ( Distributed Solving Problem)

- systemy wieloagentowe MAS (Multiagent System).

DSP wykorzystuje się wtedy, gdy jeden duży problem dzieli się na mniejsze podproblemy i przydziela je poszczególnym węzłom rozproszonego systemu do rozwiązania.

MAS natomiast koncentruje się przede wszystkim na poszczególnych modułach wykonujących podzadania. Każdy z nich jest przydzielany suwerennemu autonomicznemu programowi (agentowi). Naturalną cechą takich systemów jest rozproszenie, które może być:

- przestrzenne, np. zbieranie informacji od czujników znajdujących się w różnych miejscach pojazdu

- funkcjonalne, gdzie programy eksperckie mają za zadanie rozwiązać określone problemy w różnych środowiskach programowych.

Korzyści wynikające ze sterowania systemów rozproszonych są następujące:

- zwiększona moc obliczeniowa wynikająca ze stosowania przetwarzania równoległego

- zwiększona niezawodność, istnieje bowiem możliwość takiego zaprojektowania systemu, aby w 
chwili awarii funkcje nie działającego elementu (węzła) systemu zostały przejęte przez inne działające węzły

- zwiększona adaptacyjność (rekonfigurowalność) dzięki możliwości modyfikacji programów i łatwemu podziałowi zasobów.

W pracy zostanie dokonana teoretyczna analiza (algorytmy działania) w celu rozeznania lokomotywy jako obiektu podlegającemu sterowaniu i diagnostyce. Wykorzystując panele operatorskie i sterowniki mikroprocesorowe zbudowane zostaną modele obserwacji, sterowania i diagnostyki lokomotywy. Modele te zostaną zbadane laboratoryjnie i analizowane pod kątem prawidłowej współpracy $\mathrm{w}$ inteligentnych węzłach mechatronicznych. Prace zostaną zakończone zbudowaniem prototypowego układu pomiarowo sterującego, który jest systemem rozproszonym, a którego celem jest możliwość uruchamiania i badania oprogramowania realizującego różne algorytmy układów hamulcowych.

\section{Stosowane systemy sterowania przez firmy europejskie [1 i 4]}

W znanych europejskich firmach, zajmujących się elektrycznym wyposażaniem pojazdów trakcyjnych, opracowano różne niezależne systemy sterowania. Najbardziej znane to:

- system MITRAC ${ }^{\circledR}$ firmy ADtranz, który jest rozwinięciem technologii GEATRAC, MICAS i TRACS; cechuje się bardzo elastyczną, rozłożoną architekturą; MITRAC zarządza sterowaniem kompletnego zestawu pociagu oraz poszczególnych pojazdów, włącznie z napędem; wszystkie moduły MITRAC'a są wyposażone w interfejsy MVB, łączące je z magistralą pojazdu MVB

- system AGATE ${ }^{\mathrm{TM}}$ firmy Alstom charakteryzuje się architekturę rozłożoną; każdy większy podzespół pojazdu posiada własny 32-bitowy sterownik lokalny, który realizuje także zadania diagnostyczne

- system firmy Fiat Ferroviaria (sterowania i diagnostyki pokładowej) jest stosowany w pociagach Sm3, Sm4, ETR 460, ETR 470 i ETR 480; charakteryzuje się rozłożoną architekturą i całkowitą redundancją

- system sterowania pociagu ICE posiada architekturę rozłożoną, zapewniającą zsynchronizowane funkcjonowanie dwóch wagonów silnikowych i możliwie najlepsze działanie urządzeń pociągu (redundancja elementów).

Najnowsze systemy sterowania i diagnozowania krajowych pojazdów szynowych to:

- system sterowania i diagnostyki zmodernizowanej lokomotywy ET22;w 2004 r. Zakłady Naprawcze Lokomotyw Elektrycznych w Gliwicach na podstawie dokumentacji technicznej opracowanej przez IPS „TABOR” zmodernizowały lokomotywę 201E nr 315, która otrzymała nowe oznaczenie
ET22-2000. Koncepcja i algorytmy działania systemu sterowania i diagnostyki (SySiD) lokomotywy 201Em (ET22-2000) zostały opracowane w IPS „TABOR”, natomiast wykonanie i oprogramowanie powierzono firmie WASKO (obecnie ENTE) z Gliwic

- sterownik systemu hamowania e.z.t. 16WE; w 2006 r. PESA w Bydgoszczy wyprodukowała nowy elektryczny zespół trakcyjny 16WE (ED74-01), w którym zastosowano rozproszony sterownik sterowania pneumatyki i hamulców MPS-16WE-01, opracowany i wyprodukowany przez IPS ,TABOR”

- system hamowania dla jednostki e.z.t. 15WE (oznaczenie kolejowe ED59) produkcji PESA Bydgoszcz, w którym zastosowano opracowany i wyprodukowany przez IPS „TABOR” sterownik pneumatyki i hamowania MPS-15WE.

\section{Problemy rozproszonego ukladu sterowania 3.1. Definicje i określenia}

W pełni rozproszonym systemem jest taki, w którym sterowanie, sprzęt i dane informatyczne są rozproszone. Węzłem systemu komputerowego jest zazwyczaj sterownik (PLC) lub ich grupa. Cały system staje się natychmiast rozproszonym systemem $\mathrm{w}$ sensie informatycznym, gdyż następuje rozproszenie zarówno procesów jak i zasobów sterowania.

Rozproszona struktura układu sterowania może mieć różny charakter:

- rozproszone zadania sterownicze ze względu na fizyczne oddalenie obiektów systemu

-rozproszone zadania sterownicze ze względu na ograniczoną moc obliczeniową pojedynczych sterowników

- podział zadań ze względu na przejrzystość tworzonego oprogramowania oraz szybkość jego powstawania

- podział zadań ze względu na wymaganą szybkość pracy.

Wzajemne połączenie elementów struktury rozproszonej może być różne $\mathrm{w}$ zależności od charakteru łączonych struktur:

- dla fizycznie oddalonych obiektów systemu oraz obiektów typu Master (jednostka nadrzędna) najlepsza jest sieć CAN (Controller Area Network standard szeregowej transmisji danych) dla przesyłu danych lub połączenie PWM (Pulse with modulation - modulacja szerokości impulsu) dla zespołów zadajników

- pozostałe elementy struktury mogą znajdować się blisko siebie, stąd odpowiednia byłaby sieć $\mathrm{I}^{2} \mathrm{C}$ (Inter Integrated Circuit bus - szeregowa dwukierunkowa magistrala służąca do przesyłania danych między wewnętrznymi modułami urządzenia układami scalonymi). 
Rozwinięciem idei układu sterowania cyfrowego jest system sterowania rozproszonego (rys. 1) [2]. W systemie tym czujnik pomiarowy (CP) oraz przetworniki $\mathrm{A} / \mathrm{C}$ i C/A są umieszczone bezpośrednio przy obiekcie sterowanym i połączone ze sterownikiem (komputerem) magistralą cyfrowej transmisji danych. Transmisję tę umożliwiają interfejsy cyfrowe (I), których zadaniem jest dostosowanie danych pomiarowych do przyjętego protokołu transmisji, a następnie konwersja do standardu układów wejściowych sterownika cyfrowego (komputera). Charakterystyczną cechą modelu systemu rozproszonego są opóźnienia transmisji, oraz „współzawodnictwa" różnych węzłów sieci w dostępie do mediów komunikacyjnych. Opóźnienia występujące $\mathrm{w}$ rozproszonych układach sterowania mogą mieć wpływ destabilizujący na sieć lub istotnie pogarszać jej własności dynamiczne.

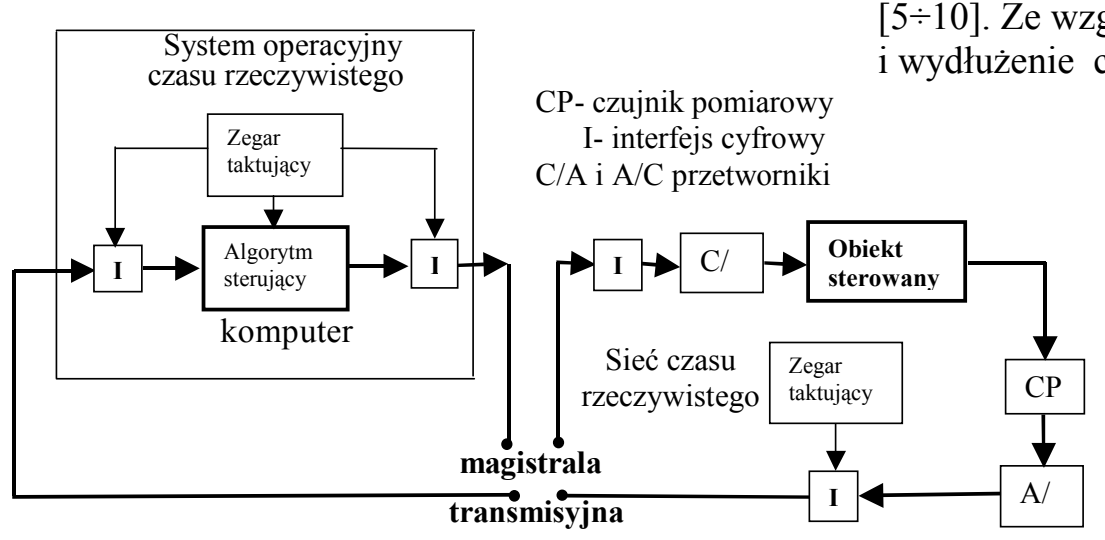

Rys. 1. Rozproszony układ sterowania

Aplikacje użytkownika, biblioteka komunikacyjna i interfejs sprzętowy zazwyczaj posiadają indywidualne cechy, które utrudniają współpracę w sieci. $\mathrm{Z}$ tego względu konieczna stała się standaryzacja, upraszczająca integrację węzłów sieci. $\mathrm{Na}$ rys.2 przedstawiono warstwowy model sieci, który ułatwia współpracę i komunikację pomiędzy poszczególnymi węzłami sieci.

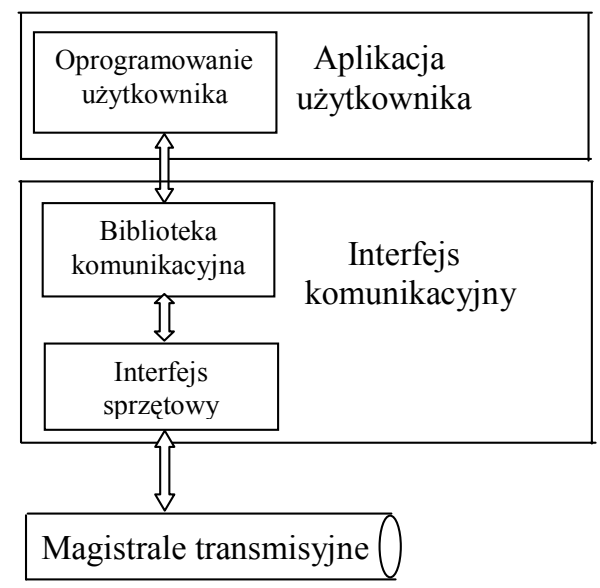

Rys. 2. Warstwowy model sieci

\subsection{Rodzaje modeli komunikacyjnych}

Podstawowo sieci klasyfikuje się ze względu na topologię oraz na ich zasięg. Ze względu na topologię sieci dzieli się na: magistralową, pierścieniową, osiową, gwiaździstą i nieregularną.

Ze względu na ich zasięg sieci dzieli się na [3]:

- lokalne (LAN - Lokal Area Network), o zasięgu kilku kilometrów

- metropolitalne (MAN - Metropolitan Area Network), o zasięgu od kilkunastu do kilkudziesięciu kilometrów, obejmujące np. zespół miejski lub aglomeracje

- rozległe (WAN - Wide Area Network),obejmujące swym zasięgiem region, kraj lub cały świat.

W automatyce zastosowanie znajduje szczególny rodzaj sieci lokalnych, LAN, zwany sieciami miejscowymi, polowymi lub przemysłowymi. Ogólny model sieci jest opracowany przez ISO i opisany $\mathrm{w}$ $[5 \div 10]$. Ze względu na wysoki koszt takiego interfejsu i wydłużenie czasu transmisji, protokoły komunikacyjne przemysłowych sieci komputerowych sa zazwyczaj stosunkowo proste i zgodne ze standardem zdefiniowanym przez ISO, opisującym strukturę komunikacji sieciowej. Pominięcie implementacji pewnych warstw między innymi ułatwia realizację uzależnień czasowych wynikających $\mathrm{z}$ warunków pracy $\mathrm{w}$ czasie rzeczywistym.

Najbardziej popularne standardy lokalnych sieci przemysłowych stosowanych w pojazdach szynowych to:

- Profibus DP - magistrala klasy Devicebus (sieci sterowników) o ograniczonej liczbie funkcji, obsługujący czujniki i urządzenia wykonawcze

- CAN - szybka magistrala klasy Sensors/Devicebus (sieci czujników/sieci sterowników) o ograniczonej liczbie funkcji.

Dla zastosowań w pojazdach szynowych istotne są dwie podklasy sieci:

- sieci czujników (ang. sensorbus), gdzie transmisja danych odbywa się na poziomie bitów

- sieci sterowników (ang. devicebus), gdzie dane są przesyłane w postaci bajtowej.

\section{Stosowane modele sieci CAN}

W realizowanym projekcie badawczym zastosowano

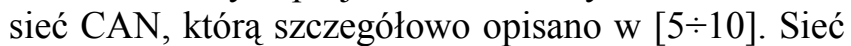
CAN powstała w latach 80-tych XX wieku w firmie Bosch i była dalej rozwijana we współpracy głównie $\mathrm{z}$ firmami Intel i Philips. Pierwszym zastosowaniem była komunikacja między sterownikami różnych 
funkcji samochodu i dziś pozostaje najpowszechniejszym rozwiązaniem w tym obszarze. CAN protokół wydajnej komunikacji szeregowej jest to szybka magistrala klasy Sensors/Devicebus o ograniczonej liczbie funkcji, nie wymagająca implementacji wszystkich warstw modelu ISO/OSI (OSI - Open System Interconnection) zaprojektowana dla systemów automatyki w pojazdach, obecnie coraz powszechniej stosowana również w przemyśle. CAN jest magistralą systemową umożliwiająca wzajemną komunikację pomiędzy modułami elektronicznymi. CAN w sieci przemysłowej to standard wykorzystywany $\mathrm{w}$ najniższej warstwie, czyli do połączenia urządzeń wykonawczych, czujników, itd. Ponieważ jest siecią multimaster (składającą się z wielu jednostek Master), dlatego możliwa jest sytuacja, że każdy moduł może mieć dostęp do szyny i jeżeli wysyła dane o odpowiednio wysokim priorytecie, zajmuje szynę na czas transmisji jednego telegramu. Modułami łączonymi za pomocą tej sieci mogą być zarówno proste układy wejścia - wyjścia, układy mikroprocesorowe, a także komputery. Właśnie dzięki możliwości podłączenia układów o dużej mocy obliczeniowej, tworzy się system realizujący funkcję inteligencji rozproszonej. W systemie CAN nie wykorzystuje się adresowania poszczególnych węzłów, przez co nie ma potrzeby informowania systemu o zmianie konfiguracji. Takie rozwiązanie ma swoje zalety:

- Elastyczność systemu; dodanie węzła do sieci CAN nie wymaga jakichkolwiek zmian w oprogramowaniu, sprzęcie, a także w warstwie aplikacyjnej

- Przepływ wiadomości; każda wiadomość ma swój identyfikator; nie wskazuje on na miejsce docelowe wiadomości, ale opisuje znaczenie danych zawartych w informacji; węzły w sieci odbierają wszystkie wysłane wiadomości i jeśli identyfikator wiadomości zostaje "zaakceptowany" przez węzeł (filtracja), to dane zawarte $\mathrm{w}$ telegramie podlegają dalszemu przetwarzaniu
- Wielodostęp (ang. multicast); w konsekwencji filtracji wiadomości, każdy węzeł może odebrać i jednocześnie wykonać odpowiednie działania na tej samej paczce informacji

- Zgodność danych; sieć CAN gwarantuje, że każda wiadomość jest jednocześnie akceptowana przez wszystkie węzły lub zostaje odrzucona; w ten sposób zgodność danych w systemie jest kontrolowana albo przez wielodostęp albo przez obsługę błędów.

Układ węzłów sieci CAN pokazano na rys. 3:

Typowy węzeł sieci CAN zawiera:

- mikroprocesor przetwarzający dane

- sterownik CAN realizujący zadania drugiej warstwy modelu OSI (podwarstwa LLC sterowania łączem logicznym oraz podwarstwa kontroli dostępu do medium MAC)

- nadajnik / odbiornik stanowiący interfejs z warstwą fizyczną sieci; układ nadajnika /odbiornika w sieci CAN może synchronicznie zapisywać jak i odczytywać dane z magistrali

- rezystory dopasowujące $\mathrm{R}=120 \Omega$

Cechami charakterystycznymi systemu CAN są:

\section{a) Dostęp do magistrali - arbitraż}

Istnieje wiele opracowanych metod dostępu do sieci, jednakże w sieci CAN zastosowano metodę typu CSMA (Carrier Sense Multiple Access), która zapewnia równouprawnienie wszystkim użytkownikom i uniezależnia sieć od awarii któregokolwiek węzła.

\section{b) Bezpieczeństwo}

Dla osiagnnięcia największego bezpieczeństwa transferu danych, we wszystkich węzłach sieci CAN zaimplementowano odpowiednie sposoby detekcji błędów, sygnalizacji i samokorekcji. węzeł 1

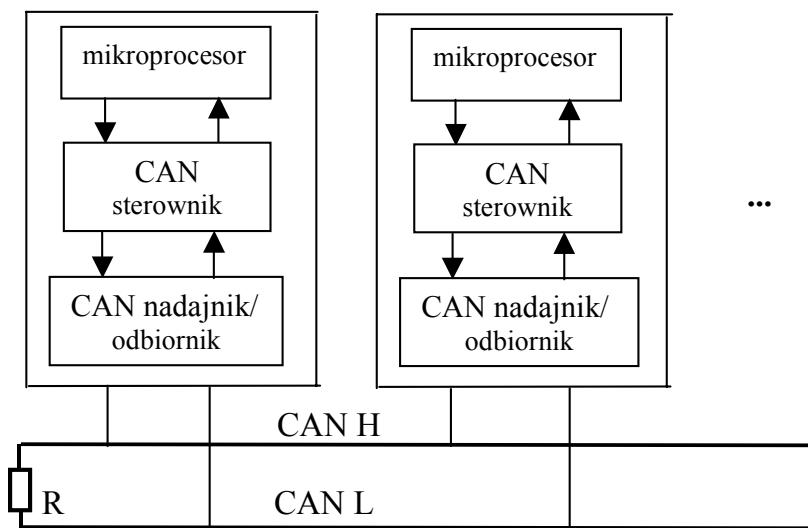

węzeł $n$

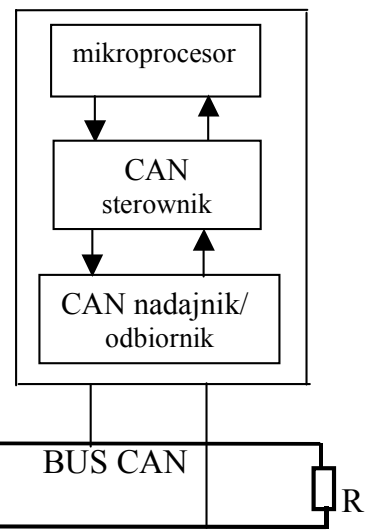

Rys. 3 Węzły sieci CAN 
c) Sygnalizacja błędów i "odzyskiwanie czasu"

Uszkodzona wiadomość jest zaznaczana przez jeden $\mathrm{z}$ węzłów wraz $\mathrm{z}$ jednoczesnym zasygnalizowaniem błędu. Możliwe jest także "odzyskanie czasu" po wykryciu błędu. Polega to na tym, iż w momencie pojawienia się błędu na szynie, w trakcie nadawania wiadomości, możliwe jest zakończenie wysyłania wiadomości.

\section{d) Ograniczenie uszkodzeń}

Węzły sieci CAN są zdolne odróżnić krótkotrwałe zakłócenia od trwałych uszkodzeń.

W przypadku wadliwego działania węzła, zostaje on wyłączony aż do momentu, w którym zakłócenie minie.

\section{e) Nieograniczona ilość modułów}

W systemie CAN ilość modułów jest teoretycznie nieograniczona. Wynika to $\mathrm{z}$ tego, że $\mathrm{w}$ sieci tej nie ma adresacji modułów, a każda wysyłana informacja może być odebrana przez wszystkie moduły (ang. broadcast).

\section{LITERATURA}

[1] Durzyński Z.: Sterowanie i diagnozowanie nowoczesnych pojazdów szynowych. Zeszyty naukowe Politechniki Poznańskiej, Maszyny Robocze i Pojazdy Nr.42,1995.

[2] Grega W.: Metody i algorytmy sterowania cyfrowego $w$ uktadach scentralizowanych $i$ rozproszonych. Wydawnictwo AGH,2004.

[3] Sacha K.: Sieci miejscowe PROFIBUS. Wydawca ZNI ,MIKOM”, Warszawa,maj 1998.

[4] Opracowanie $n r$ OR-9066 „Przeglad najnowszych systemów sterowania $i$ diagnozowania pojazdów szynowych", Poznań ,czerwiec 2006. Praca niepublikowana. Archiwum IPS „TABOR".

[5] International Standards Organization, Basic Reference Model for Open Systems Interconnection, ISO 7498,1983.

[6] CAN Specification 2.0, Part A. CAN in Automation, Am Weichselgarten 26, D-91058 Erlangen, 1999, www.can-cia.org.

[7] CAN Specification 2.0, Part B. CAN in Automation, Am Weichselgarten 26, D-91058 Erlangen, 1999, www.can-cia.org.

[8] CAN Implementation. CAN in Automation, Am Weichselgarten 26, D-91058 Erlangen, 2000, www.can-cia.org.

[9] ISO 11898, Road vehicles - Controller area network (CAN) - Part 1: Data link layer and physical signalling, 1999.

[10] ISO 11898, Road vehicles - Controller area network (CAN) - Part 2: High-speed medium access unit, 1999. 